\title{
Program IbPE untuk Meningkatkan Usaha UKM Berbahan Dasar Kulit
}

\author{
Syamsuri ${ }^{1}$, Wiwik Widyo ${ }^{2}$, Evi Yuliawati ${ }^{3}$, Yustia Wulandari ${ }^{4}$ \\ ${ }^{1}$ Teknik Mesin, Institut Teknologi Adhi Tama Surabaya \\ Email: syamsuri@itats.ac.id \\ ${ }^{2}$ Teknik Arsitektur, Institut Teknologi Adhi Tama Surabaya \\ ${ }^{3}$ Teknik Industri, Institut Teknologi Adhi Tama Surabaya \\ ${ }^{4}$ Teknik Kimia, Institut Teknologi Adhi Tama Surabaya
}

\begin{abstract}
Science and Technology Program for Export Products (IbPE) have 2 partners, namely entrepreneurs bags that use basic leather. Partner 1 is a businessman purses, bags and shoes that are located on Jl. Sidoluhur No. 15 RT. 05 RW. 01 Dilem, Kepanjen-Malang, East Java, Indonesia. Then Partner 2 is an entrepreneur focusing on bag products located in Kendensari RT. 02 RW. 01 No. 49 Tanggulangin, Sidoarjo, East Java, Indonesia. So far, Partner 1 as a leather wallet entrepreneurs markets their products directly to consumers in the form of retail or wholesale. Consumer for product's Partner 1 is wallet and other products in the surrounding area both in the country and abroad to Singapore. Whereas for Partner 2 its marketing is done by dependent order, even though the product of partner 2 has reached to Timor Leste and China. The process is still conventional, that is most of the process is done manually relying on the skills of the workers. It becomes an obstacle for Partners to develop their business. Access to export marketing tends to be rather difficult, so delivery to meet the needs of overseas consumers is hampered. The lack of education and the ability of workers is also a serious obstacle for Partners. Seeing the problems experienced by Partners, the Implementing Team of IbPE aims to, increase the productivity of Partners, in order to potentially export higher and to be able to create independence partners. It can also increase the competitiveness of similar industries. From field observations and direct interviews with Partners, there are four aspects to focus in this IbPE program: product, production, marketing and process. Implementation of IbPE program is expected to assist partners in improving and developing the business both in quality and quantity. Besides, it helps Partner to look for market gaps for export products because unavailable facilities are overcome with modem procurement making it easier for partners to surf and to gain a wider market.
\end{abstract}

Keywords: craft products from leather, product export, marketing

\begin{abstract}
ABSTRAK
Program Iptek Bagi Produk Ekspor (IbPE) ini memiliki 2 Mitra, yaitu pengusaha tas yang menggunakan bahan dasar kulit. Mitra 1 adalah pengusaha dompet, tas dan sepatu yang berlokasi di Jl. Sidoluhur No. 15 RT. 05 RW. 01 Dilem KepanjenMalang, Jawa Timur, Indonesia. Kemudian Mitra 2 adalah pengusaha yang focus pada produk tas yang berlokasi di Kendensari RT. 02 RW. 01 No. 49 Tanggulangin, Sidoarjo, Jawa Timur, Indonesia. Selama ini Mitra 1 sebagai pengusaha dompet kulit memasarkan produknya langsung kepada konsumen dalam betuk enceran maupun grosir. Konsumen untuk produk Mitra 1 memasarkan dompet serta poduk lainnya di daerah malang sekitarnya baik dalam negri maupun luarnegeri hingga ke Singapura. Sedangkan untuk Mitra 2 pemasarannya dilakukan dengan tergantung pemesanan, meskipun demikianproduk mitra 2 telah sampai ke Timor Leste dan China. Proses pengerjaan yang masih konvensional yaitu sebagian besar proses dilakukan secara manual mengandalkan ketrampilan para pekerja, hal tersebut menjadi penghambat Mitra untuk dapat mengembangkan usahanya. Akses menuju pemasaran ekspor cenderung agak sulit sehingga pengiriman untuk memenuhi kebutuhan konsumen di Luar Negeri menjadi terhambat. Minimnya pendidikan dan kemampuan pekerja juga menjadi kendala serius bagi Mitra. Melihat permasalahan yang dialami oleh Mitra, maka Tim Pelaksana IbPE Pengusaha Produk Kerajian Kulit bertujuan untuk meningkatkan produktivitas Mitra agar berpotensi ekspor lebih tinggi serta untuk dapat menciptakan kemandirian Mitra dan meningkatkan daya saing pada industri sejenis. Dari hasil pengamatan di lapangan dan wawancara langsung dengan Mitra, terdapat empat aspek yang menjadi fokus pada program IbPE ini yaitu produk, produksi, pemasaran dan proses. Pelaksanaan program IbPE diharapkan dapat membantu Mitra dalam meningkatkan dan mengembangkan usaha baik secara kualitas maupun kuantitas. Disamping itu membantu Mitra mencari celah pasar untuk produk ekspor karena fasilitas yang tidak tersedia diatasi dengan pengadaan modem sehingga memudahkan Mitra untuk dapat berselancar untuk mendapatkan pasar yang lebih luas.
\end{abstract}

Kata kunci: kerajinan produk kulit, produk ekspor, pemasaran 


\section{PENDAHULUAN}

Berikut ini adalah permasalahan pada UKM yang teridentifikasi oleh pengusul seperti pada Tabel 1 berikut ini:

Tabel 1. Permasalahan pada UKM Mitra

\begin{tabular}{|c|c|c|}
\hline Aspek & Mitra 1. Lufas Gallery & Mitra 2. Rafi Jaya Collection \\
\hline $\begin{array}{l}\text { Bahan } \\
\text { Baku }\end{array}$ & $\begin{array}{l}\text { 1. Keterlambatan pasokan bahan baku } \\
\text { yang di impor dari China sehingga } \\
\text { Due date penyerahan produk yang } \\
\text { sering terlewati. }\end{array}$ & $\begin{array}{l}\text { Untuk bahan baku, mitra } 2 \text { tidak } \\
\text { mengalami permasalahan yang } \\
\text { urgent, karena bahan baku } \\
\text { terpenuhi sesuai } \\
\text { pemesanan }\end{array}$ \\
\hline Produksi & $\begin{array}{l}\text { 2. Karena keterlambatan pasokan } \\
\text { bahan baku, maka Due date } \\
\text { penyerahan produk yang sering }\end{array}$ & $\begin{array}{l}\text { Mesin dan peralatan yang } \\
\text { digunakan dalam proses produksi } \\
\text { cenderung konvensional }\end{array}$ \\
\hline
\end{tabular}

Proses 3. Ruang produksi yang dimiliki kedua

Mitra tidak beraturan, sehingga terlihat cenderung tidak rapi karena semua bahan baku dan bahan pendukungnya bercampur menjadi satu.

Produk

Manajemen

4. Telah memiliki tim SDM yang khusus menangani desain produk tetapi desainnya masih monoton

5. Belum memiliki ketrampilan desain yang baik.
Penempatan mesin dan peralatan terkesan seadanya sehingga terdapat waktu delay dalam penyelesaian produk

Desain produk masih berdasarkan pemesanan dan cenderung tidak up to date atau masih meniru produk yang ada di pasaran sehingga belum ada originalitasnya.

Keterbatasan dalam SDM khusus yng menangani desain dan peralatan komputer untuk desain

6. Kedua mitra belum memiliki perencanaan perencanaan pengembangan usaha yang matang khususnya untuk komoditas ekspor. Belum memiliki SDM yang khusus menangani pemasaran serta kapasitas SDM dalam menangani administrasi, perencanaan produksi, dan audit/akunting harus diupgrade.

Pemasaran 7. Kedua mitra belum memiliki SDM khusus yang menangani pemasaran prodduk terutama untuk komoditas ekspor ekspor.

8. Belum memiliki media pemasaran khusus untuk produk ekspor.

SDM 9. SDM yang dimiliki oleh Mitra 1, SDM yang dimiliki mayoritas mayoritas memberdayakan para ibu rumah tangga sekitarya sebagai berpendidikan tertinggi tenaga produksi. Sehingga masih memungkinkan peluang untuk meningkatkan kemampuan SDM SMA/SMK/sederajat. Selain itu mitra telah meberdayakan para warga yang memiliki kebutuhan yang ada.

Fasilitas 10.Belum memiliki fasilitas internet yang dapat menunjang pemasaran online, Karen jika pasar ekspor tercapai maka fasilitas ini menjadi sangat penting. Belum memiliki

Finansial 11.Selama ini keuntungan yang didapat selalu diputar sebagai modal produksi selanjutnya. Jika komoditas ekspor telah tercapai, hal ini dapat menjadi permasalahan serius karena akan menghambat proses produksi. Sehingga secara tidak langsung akan menghambat proses penyerahan produk ke konsumen. 


\section{Prioritas Permasalahan Mitra}

Kemudian berdasarkan kesepakatan antara Mitra dengan Tim Pelaksana PPPE, maka pelaksanaan kegiatan ini akan fokus pada permasalahan sebagai berikut :

1. Aspek Produksi

Permasalahan pada investasi yang tidak terlalu besar untuk peralatan, akan menemukan permasalahan baru jika pasar ekspor telah diraih karena hal ini akan berakibat pada peningkatan jumlah kapasitas produksi.

2. Aspek Proses

Ruang produksi akan terasa kurang luas apabila terjadi peningkatan jumlah permintaan. Sehingga penataan lay out produksi sangat diperlukan.

3. Aspek Pemasaran

Pemasaran yang dilakukan Mitra kurang agresif karena masih mengandalkan pemesanan pre-order.

4. Aspek SDM

Fungsi SDM belum teridentifikasi dengan jelas. Pemilik UKM Mitra harus melakukan banyak fungsi seperti, administrasi, perencanaan dan audit. Hal ini disebabkan karena sebagaian besar karyawan bekerja untuk bagian produksi dan pengelolaan ekspor impor.

\section{METODE PELAKSANAAN}

Mengacu pada permasalahan yang telah disepakati bersama dengan Mitra, maka ada beberapa luaran yang akan ditargetkan untuk dihasilkan dalam 3 tahun. Jenis luaran akan dikembangkan berdasarkan bidang dan prioritas permasalahan

Tabel 2. Target Luaran

\begin{tabular}{|c|c|c|c|}
\hline Bidang & Solusi yang Ditawarkan & $\begin{array}{l}\text { Metode Pendekatan (Prosedur, } \\
\text { Rencana Keg, Partisipasi Mitra) }\end{array}$ & Target yang Diharapkan \\
\hline Produksi & $\begin{array}{l}\text { - Peningkatan kapasitas produksi untuk } \\
\text { memenuhi pasar ekspor. } \\
\text { - Peningkatan kemampuan SDM dalam } \\
\text { bidang produksi, mulai dari } \\
\text { perencanaan hingga pengendalian } \\
\text { proses produksi. }\end{array}$ & $\begin{array}{l}\text { Melakukan rekayasa mesin dan } \\
\text { peralatan yang dibutuhkan oleh } \\
\text { Mitra. } \\
\begin{array}{l}\text { Mengikuti pelatihan tentang } \\
\text { perencanaan dan pengendalian } \\
\text { produksi }\end{array}\end{array}$ & $\begin{array}{l}\text { Kapasitas produksi Mitra meningkat. } \\
\text { SDM Mitra mampu melakukan } \\
\text { perencanaan dan pengendalian produksi } \\
\text { Proses produksi tepat waktu. }\end{array}$ \\
\hline Proses & $\begin{array}{l}\text { Peningkatan kemampuan mitra dalar } \\
\text { perancangan lay out ruang display agar } \\
\text { proses berjalan efektif dan efisien. }\end{array}$ & $\begin{array}{l}\text { Melakukan rekayasa lay out ruan€ } \\
\text { display }\end{array}$ & $\begin{array}{l}\text { Mitra memiliki lay out pada } \\
\text { ruang display yang mudah } \\
\text { dikenali oleh konsumen. }\end{array}$ \\
\hline Pemasaran & $\begin{array}{l}\text { - Peningkatan kemampuan SDM dalam } \\
\text { memasarkan produk. } \\
\text { - Peningkatan teknik dan media } \\
\text { pemasaran dalam rangka memasuk } \\
\text { pasar ekspor yang lebih luas. }\end{array}$ & $\begin{array}{l}\text { Mengikuti pelatihan dan workshof } \\
\text { tentang pemasaran produk ekspor. } \\
\text { Membuat katalog produk (baik } \\
\text { online maupun printed) }\end{array}$ & $\begin{array}{l}\text { Mitra memiliki pangsa pasar produk } \\
\text { yang lebih luas. }\end{array}$ \\
\hline SDM & $\begin{array}{l}\text { - Peningkatan kemampuan SDM dalam } \\
\text { pengelolaan proses ekspor impor } \\
\text { - Peningkatan kemampuan SDM dalam } \\
\text { proses produksi }\end{array}$ & $\begin{array}{l}\text { Mengikuti pelatihan dan workshof } \\
\text { tentang proses ekspor impor dar } \\
\text { produksi }\end{array}$ & $\begin{array}{l}\text { Mitra memiliki kemampuan ekspor } \\
\text { impor dan produksi. }\end{array}$ \\
\hline
\end{tabular}


Tabel 3. Indikator Pencapaian Target Luaran

\begin{tabular}{|c|c|c|}
\hline Bidang & Target yang Diharapkan & Indikator \\
\hline Produksi & $\begin{array}{l}\text { Kapasitas produksi Mitra meningkat. } \\
\text { SDM Mitra mampu melakukan perencanaan } 0 . \\
\text { dan pengendalian produksi } \\
\text { Proses produksi tepat waktu }\end{array}$ & $\begin{array}{l}\text { Investasi mesin dan peralatan produksi } \\
\text { Mitra memiliki sistem perencanaan dan pengendalian } \\
\text { produksi yang terdokumentasi } \\
\text { Kapasitas produksi per bulan (unit) } \\
\text { Prosentase keterlambatan order terhadap due date yang } \\
\text { telah disepakati }\end{array}$ \\
\hline Proses & $\begin{array}{l}\text { Mitra memiliki lay out pada ruang } \\
\text { display yang mudah dikenali oleh } \\
\text { konsumen }\end{array}$ & Prosentase produk reject \\
\hline Pemasaran & $\begin{array}{l}\text { Mitra memiliki pangsa pasar produk yang } \\
\text { lebih luas }\end{array}$ & $\begin{array}{l}\text { Mitra memiliki SDM yang dapat mengelola media } \\
\text { pemasaran secara mandiri } \\
\text { Mitra dapat melakukan kontak dagang melalui website } \\
\text { Mitra memiliki katalog online } \\
\text { Mitra memiliki katalog printed } \\
\text { Mitra terdaftar pada pada direktori Pusat Pendidikan dan } \\
\text { Promosi Ekspor Daerah (P3ED) Jawa Timur } \\
\text { Jumlah transaksi ekspor } \\
\text { Nilai transaksi ekspor (juta) }\end{array}$ \\
\hline SDM & $\begin{array}{l}\text { Mitra memiliki kemampuan ekspor impor dan } \\
\text { produksi yang lebih baik }\end{array}$ & $\begin{array}{l}\text { Mitra memiliki SDM yang dapat mengelola dan } \\
\text { mengendalikan proses produksi. } \\
\text { Mitra memiliki SDM yang dapat mengelola ekspor impor }\end{array}$ \\
\hline
\end{tabular}

\section{HASIL DAN PEMBAHASAN}

Sesuai dengan tujuan pada program IbPE, sampai pada laporan kemajuan ini terdapat beberapa hasil yang telah dicapai. Kegiatan IbPE yang dilaksanakan sejalan dengan solusi yang ditawarkan untuk menyelesaikan permasalahan yang dihadapi oleh Mitra. Berikut adalah solusi yang ditawarkan beserta kegiatan IbPE yang telah dan akan dilaksanakan seperti terlihat pada Tabel 4 di bawah ini. 
Tabel 4. Rekapitulasi Ketercapaian Kegiatan PPPE

\begin{tabular}{|c|c|c|c|}
\hline Bidang & Prioritas Permasalahan & Luaran & Ketercapaian Kegiatan \\
\hline Produksi & $\begin{array}{l}\text { 1. Mesin dan peralatan yang } \\
\text { digunakan dalam proses produksi } \\
\text { cenderung konvensional. } \\
\text { 2. Permasalahan kapasitas produksi } \\
\text { menjadi penting apabila pasar } \\
\text { ekspor telah diraih. } \\
\text { 3. Due date penyerahan produk } \\
\text { yang sering terlewati. }\end{array}$ & $\begin{array}{l}\text { Mesin Seset untuk } \\
\text { menunjang proses } \\
\text { produksi } \\
\text { Mesin Lis untuk } \\
\text { menunjang proses } \\
\text { produksi }\end{array}$ & $\begin{array}{l}\text { Telah Terlaksana } \\
\text { Dapat meningkatkan } \\
\text { kapasitas produksi dan } \\
\text { mengurangi } \\
\text { keterlambatan } \\
\text { pemenuhan order }\end{array}$ \\
\hline Proses & $\begin{array}{l}\text { 1. Ruang produksi dan display yang } \\
\text { dimiliki kedua Mitra tidak } \\
\text { beraturan, bahan baku dan sisa- } \\
\text { sisanya bercampur menjadi satu. }\end{array}$ & $\begin{array}{l}\text { Rekayasa Rak } \\
\text { Display }\end{array}$ & $\begin{array}{l}\text { Telah Terlaksana } \\
\text { Produk tertata rapi } \\
\text { sehingga memudahkan } \\
\text { konsumen untuk memilih } \\
\text { produk yang diinginkan }\end{array}$ \\
\hline Pemasaran & $\begin{array}{l}\text { 1. Belum memiliki SDM khusus } \\
\text { yang menangani pemasaran } \\
\text { produk } \\
\text { 2. Tidak memiliki media pemasaran } \\
\text { yang spesifik untuk produk } \\
\text { ekspor }\end{array}$ & $\begin{array}{l}\text { Membuat katalog } \\
\text { printed } \\
\text { Printer untuk } \\
\text { memudahkan Mitra } \\
\text { melakukan proses } \\
\text { administrasi } \\
\text { Modem untuk } \\
\text { mempermudah } \\
\text { Miitra untuk } \\
\text { transaksi online }\end{array}$ & $\begin{array}{l}\text { Telah Terlaksana } \\
\text { Dapat meningkatkan } \\
\text { transaksi Mitra }\end{array}$ \\
\hline SDM & $\begin{array}{l}\text { 1. Belum memiliki SDM khusus } \\
\text { yang menangani proses ekspor } \\
\text { impor }\end{array}$ & $\begin{array}{l}\text { Pelatihan ekspor } \\
\text { impor } \\
\text { Pelatihan produksi }\end{array}$ & $\begin{array}{l}\text { Direncanakan pada } \\
\text { tahap berikutnya }\end{array}$ \\
\hline
\end{tabular}

\section{Dokumentasi Pelaksanaan Kegiatan Program IbPE}

\section{Serah terima barang}

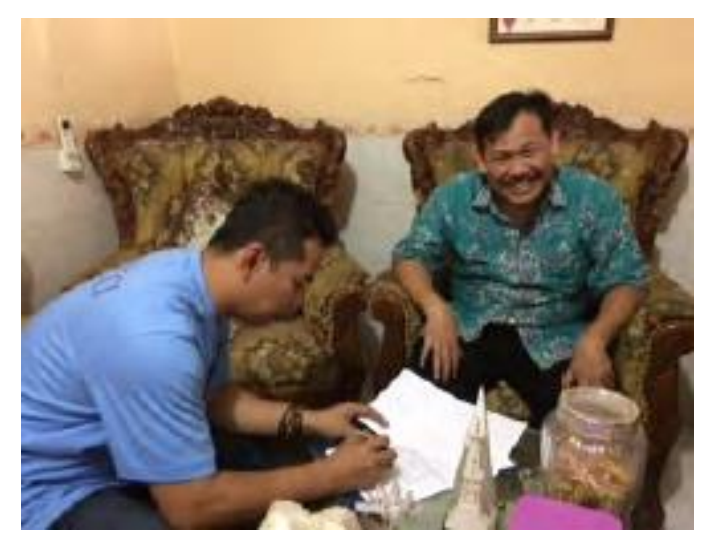

Gambar 1. Serah terima barang untuk Mitra 1 
2. Pengadaan mesin seset

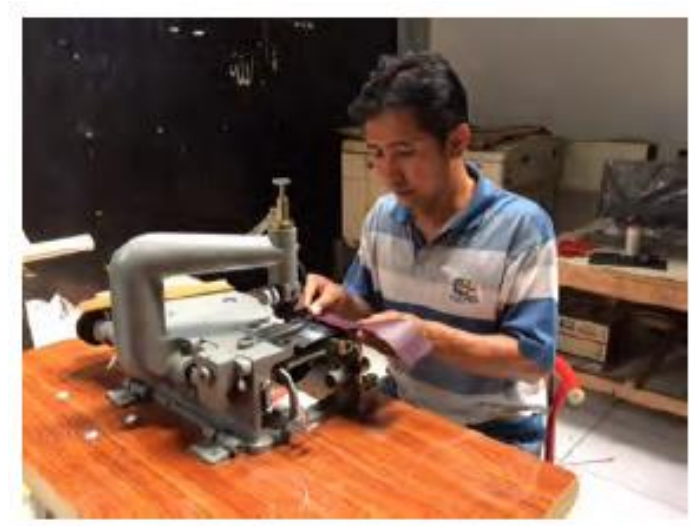

Gambar 2. Mesin seset

\section{Pengadaan mesin lis}

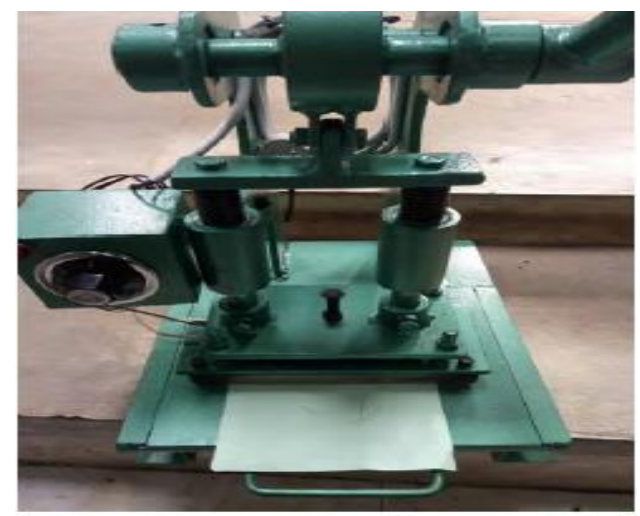

Gambar 3. Mesin lis

\section{Pengadaan rak display}

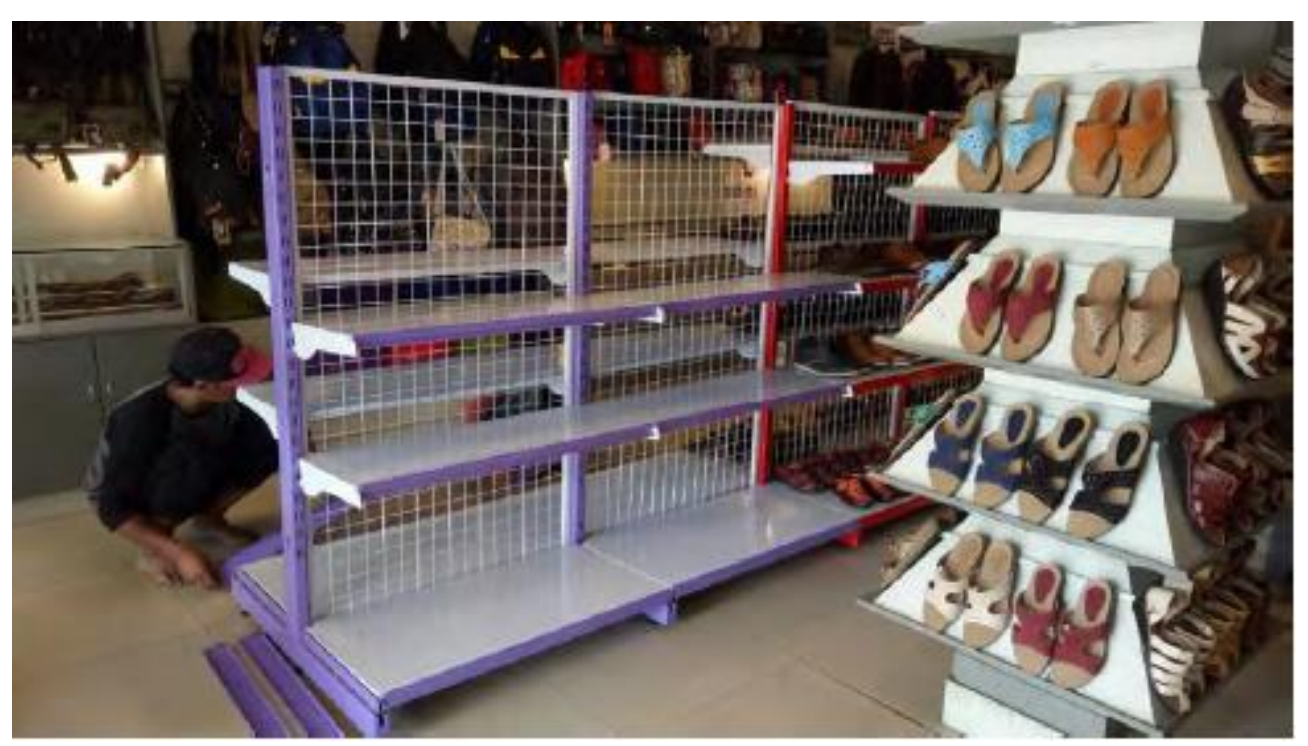

Gambar 4. Rak display 


\section{Pengadaan printer $\&$ modem}

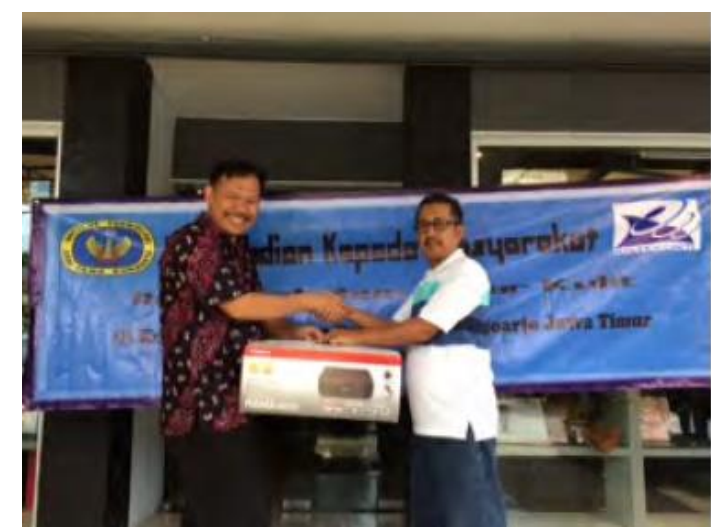

(a) Printer

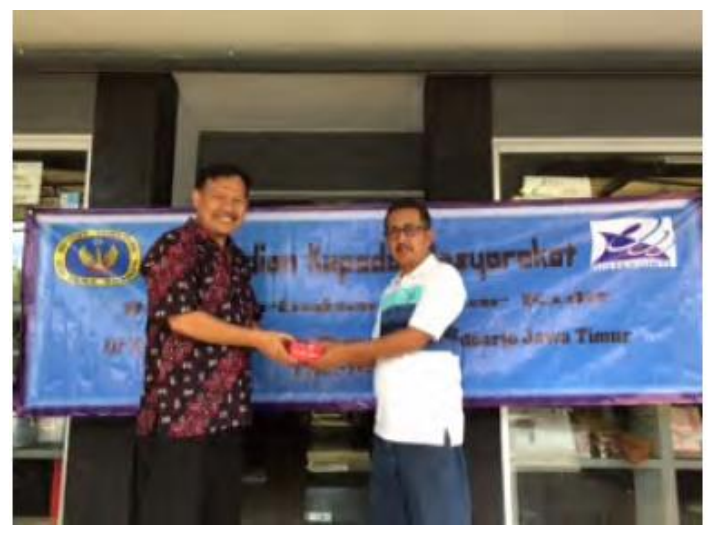

(b) Modem

Gambar 5 pengadaan printer dan modem

\section{Pengadaan catalog printed}
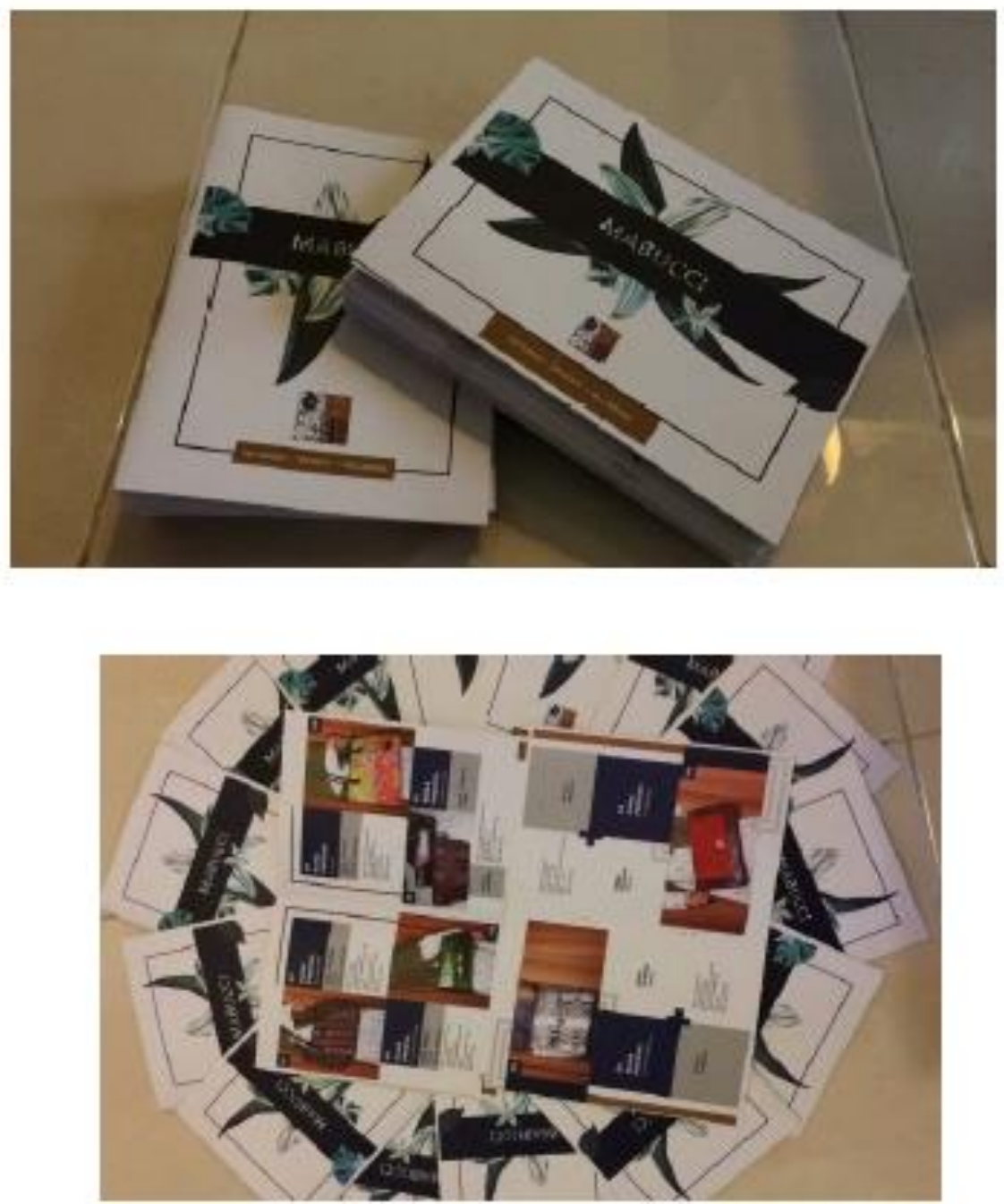

Gambar 6. Catalog printed 


\section{Pengadaan kamera}

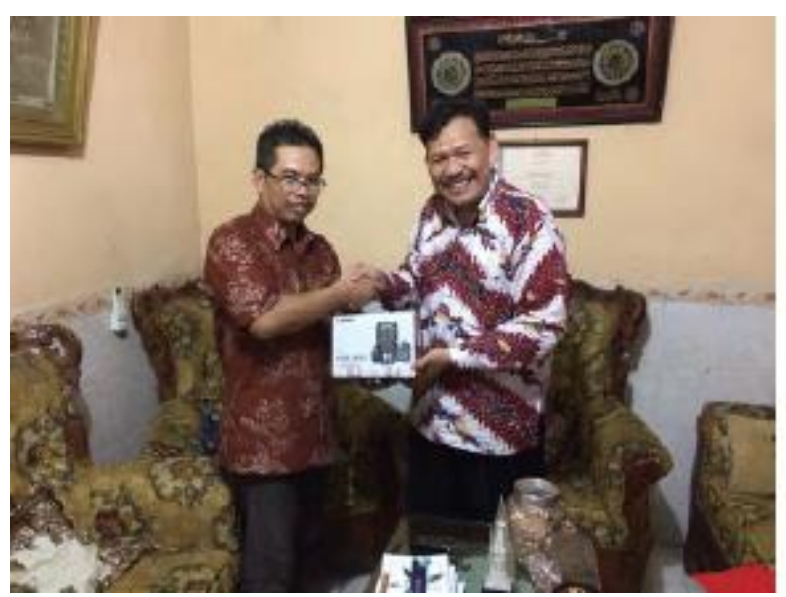

Gambar 7. Kamera DSLR

\section{KESIMPULAN}

Dari data-data yang diperoleh dapat ditarik suatu kesimpulan sebagai berikut: 1) Pengadaan mesin dan peralatan penunjang produksi: mesin seset dan mesin lis dapat membantu Mitra dalam memenuhi order dari konsumen. Kapasitas produksi Mitra meningkat seiring dengan ketersediaan mesin ini. 2) Kesulitan Mitra mencari celah pasar untuk produk ekspor karena fasilitas yang tidak tersedia diatasi dengan pengadaan modem sehingga memudahkan Mitra untuk dapat berselancar untuk mendapatkan pasar yang lebih luas. 3) Pengadaan printer memudahkan Mitra untuk kegiatan administrasi. 4) Untuk lebih mengenalkan produknya pada konsumen disediakan bookled printed yang dapat dibagikan pada konsumen saat pameranKesimpulan hasil pengabdian dapat dipaparkan pada bagian ini.

\section{UCAPAN TERIMA KASIH}

Ucapan terima kasih kami ucapkan kepada Ristek-Dikti melalui Hibah Pengabdian Kepada Masyarakat DIKTI khususnya Iptek Bagi Produk Ekspor (IbPE) yang membantu terlaksananya kegiatan pengabdian kepada masyarakat ini.

\section{DAFTAR PUSTAKA}

Carcano, E. and Portioli, S., (2014). Integrating Inspection-Policy Design in Assembly-Line Balancing. International Journal of Production Research. 44(18-19), pp. 4081-4103.

Ginting, R., (2007). Sistem Produksi. Yogyakarta: Graha Ilmu.

Grzechca, W., (2011). Cycle Time in Assembly Line Balancing Problem. Journal of Industrial Engineering. 22, pp. 171-174.

Nasution, A. H., (2009). Perencanaan dan Pengendalian Produksi, Institut Teknologi Sepuluh Nopember Surabaya. 